\begin{tabular}{|c|c|}
\hline 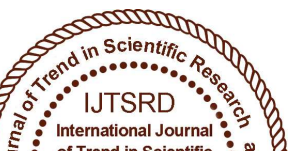 & $\begin{array}{l}\text { International Journal of Trend in Scientific } \\
\text { Research and Development (IJTSRD) }\end{array}$ \\
\hline 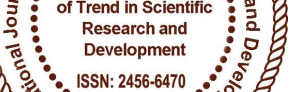 & International Open Access Journal \\
\hline 000 & ISSN No: 2456 - 6470 | www.ijtsrd.com | Volume - 2 | Issue - 3 \\
\hline
\end{tabular}

\title{
Socio Economic Conditions of Women Agricultural Labours in Thirukandeeswaram Panchayat of Thiruvarur District
}

\author{
Muhammed Atheeque. P. P \\ Ph.D Research Scholar, Department of Sociology, \\ Bharathidasan University, \\ Tiruchirappalli, Tamil Nadu, India
}

\author{
B. Chitra \\ Ph.D Research Scholar, Department of \\ History, Bharathidasan University, \\ Tiruchirappalli, Tamil Nadu, India
}

\section{ABSTRACT}

The study aimed to find out the socio economic conditions of agricultural women labour and to examine the pattern of income, expenditure and savings of agricultural women labour of Thirukandeeswaran Panchayath. The nature of study is descriptive. A questionnaire was used for collection of data. The study find out that more than two-thirds of the population of India is dependent on agriculture. Though Green Revolution technologies enhanced agricultural productivity, they also widened economic disparities and deepened gender discrimination in community life. The introduction of capital intensive technologies in the agricultural sector has had differential impact on men and women and women have been adversely affected due to lack of access to technology. Agriculture is the back bone of many developing countries. Women account for more than half of the work force by participating in different activities, either directly or indirectly. The gender division of labor varies from one society and culture to another, and within each culture external circumstances influence the level of activity.

Keywords: Women Agriculture Labours, SocioEconomic Condition and Green Revolution

\section{INTRODUCTION}

Agriculture has been the oldest activity practiced by the people in civilized world. Though many of the developed countries have moved away from the agriculture to industrialization as their main stay of economic activity, there is no ruling out of agriculture as part of the basic economic activity in any part of the world. There are still certain parts of globe where agriculture is predominantly influential in determining well-being of the people.

India is also such a country, where about $70 \%$ of the labour force is employed in the agriculture sector. Although in the recent years the share of agriculture in gross domestic product is coming down, still agriculture is the predominant sector of the economy and impacts the well-being of the other sectors. Women are the back bone of the agricultural force. The majority of the employed women are engaged in agricultural work. According to the National Family Health Survey-3 (NFHS-3), 60 out of 100 women are engaged in agricultural work. If at all there is any enterprise, since the dawn of civilization, in which women played a significant role or participated in large numbers, it is nothing but agriculture. This is because agriculture has largely been a family enterprise.

The Role of Women in Agriculture and its Connected Fields

Rural women performs numerous labor intensive jobs such as weeding, hoeing, grass cutting, picking, cotton stick collections, separation of seeds from fiber. Women are also expected to collect wood from fields. This wood is being used as a major fuel source for cooking. Because of the increasing population pressure, over grazing and desertification, women face difficulties in searching of fire wood. Clean 
drinking water is another major problem in rural areas. Like collection of wood, fetching water from remote areas is also the duty of women because a rural woman is responsible for farm activities, keeping of livestock and its other associated activities like milking, milk processing, and preparation of ghee are also carried out by the women.

\section{Significance of the study}

Women account more than half of the total community and their contribution in securing their family food demand is of great importance. But the society gave them less attention. Therefore, the study could be significant for decision makers in providing valuable information with regard to the role of women in agriculture, other activities and work load, and hence formulate gender sensitive development projects. From Census data 2001 and 2011, it is evident that the number of agricultural labourers has increased and the number of cultivators has decreased. In $2001,31.7 \%$ of workforce was cultivators and $26.5 \%$ were working as agricultural labourers, whereas in 2011 they are $24.6 \%$ and $30 \%$ respectively. This shows a decline in number of cultivators by $7.1 \%$ and increase in number of agricultural labourers by $3.5 \%$. Women today play a vital role in agriculture - as female agricultural labourers as farmers, co-farmers, female family labour and (with male out-migration, widowhood, etc.) as managers of farms and farm entrepreneurs. Threefourths of women workers are in agriculture. Among rural woman workers, 87 per cent are employed in agriculture as labourers and cultivators.

\section{Statement of the Problem}

Women in India play dominate and important role in agriculture production. Nowadays there are visible changes in women participation in agriculture production because of thegreater opportunities, education and employment. Large number of skilled women labor force employed in various organization and societies and they are aggressively fighting and opposed to restrict them in agricultural production. In agriculture sector the participating women have less education and technical skills and majority of them use low yielding and labour intensive, and traditional farm practices which may adversely affect agricultural production.

Women usually have limited accesses to resources and opportunities and their productivity remains low relative to their potential. Due to lack of awareness in our society women's role has not been recognized. Lynda, 1991 noted that we live in a society in which there is substantial level of gender inequality. The inequality in the provision of education reflects the deep rooted tradition and values within the ideological, political, economic and sociocultural structure of societies. In terms of ownership of property, the women in this country have no equal right as men. In addition, the dominance ofmen in various income generating activities affects highly the economic empowerment of women.

\section{Objectives}

1. To study the socio economic conditions of agricultural women labour

2. To examine the pattern of income, expenditure and savings of agricultural women labour

\section{Methodology}

The present study has been conducted at the Thirukkandeeswaram village. It is a medium size village located in Nannilam of Thiruvarur district, Tamil Nadu with total 415 families residing. This village has population of 1549 of which 779 are males while 770 are females as per Population Census 2011. It is the gram Panchayat of Thirukkandeeswaram village. The total geographical area of village is 280.22 hectares. Descriptive research design has been adopted for this study. There are 78 families in the village who go for wage labour. $50 \%$ of families are selected for the study, thus the sample size become 38 women, hailing from two different castes. The study mainly depends on the primary data. The data is collected from the agricultural women labours through a questionnaire. For the collection of primary data from the selected female of Thirukandeeswaram, Thiruvarur District, questionnaire is used. The questionnaire consists of closed-ended and open ended items. 


\section{RESULT AND DISCUSSION}

Table -1: Age wise classification of the respondents

\begin{tabular}{|c|l|l|l|}
\hline S. No & Age & No .of Respondent & Percentage \\
\hline 1. & $21-30$ & 3 & 7.89 \\
\hline 2. & $31-40$ & 16 & 42.10 \\
\hline 3. & $41-50$ & 9 & 23.68 \\
\hline 4. & $51-60$ & 8 & 21.05 \\
\hline 5. & $61-70$ & 2 & 5.26 \\
\hline Total & & 38 & 100 \\
\hline
\end{tabular}

Sources: Primary data

The table - 1 shows $7.89 \%$ of the respondents are 21 30 years old, $42.10 \%$ of the respondents are $31-40$ year old, 23.68 of the respondents are 41 - 50 years old, $21.05 \%$ of the respondents are $51-60$ years old and $5.26 \%$ of the respondents are $61-70$ years old. Middle aged agriculture wage labours are mostly preferred by landlord because they can work hard for more house and with experience. They can do the work with perfection. Aged women are not preferred by the reasons for biological problems in carrying things, climbing up and down, working in long hours etc. moreover, they were having bronchitis and other breathing problems receding Asthma.

Thus, it has to be seen as sequence rather than different age groups. It is a continuum to five categories. And every category has different commitments, predicaments, inabilities and nonacceptance from the society. Analysis to this tableinterims to caste studies which were sufficient for understanding the rural women as a group. Particularly, agricultural laboures, their former work to health, is entirely different from the women to other classes. Similarly, their concept of pace, adjustment with life, is entirely different from other section of societies. Apart from these, they also chased by the family commitments such as educational expenditure to children to different age groups, day-to-day expenditure for food, and other consumables like oil, groceries, milk, ratable for children, pressurize them to go for agricultural labour inspire to the problems involved in it. In addition, they occasionally spend medical grounds for which women folk support the family than men folk. Moreover, it is a women folk which gets loan because they keep it their mind as soon as they get their surplus money. Thus, the level of indebtedness is more with on agriculture then her counterpart. There is no liberty form this social set up form our past, present and future women born in rural society. There is no defense mechanism evolved so far.

\section{Table - 2}

\section{Religion of the Respondents}

\begin{tabular}{|r|l|l|l|}
\hline S. No & Religion & $\begin{array}{l}\text { No } \\
\text { Respondent }\end{array}$ & Percentage \\
\hline 1. & Hindu & 13 & 34.21 \\
\hline 2. & Christian & 25 & 65.78 \\
\hline Total & 0 & 38 & 100 \\
\hline
\end{tabular}

Sources: Primary data

This table shows that $34.21 \%$ of the respondents are belonging to Hindu religion and $65.78 \%$ respondents are belonging to Christian religion. This conversion in Christianity was a historical phenomenon goes back to French rule of Pondicherry, Karaikal etc. The original idea was to get rid of caste ridden Indian society and to come up in culturally superior French way of living-Liberty, Equality and Fraternity. However, the overall social set up was not targeted by neither the Indian government nor the Christian community. Thus, the living condition remains the same in spite of the conversion to Christianity for many generations. For that matter, no religion promises better way of living. It is only the concept of human equality, treatment of workers in par with owners which has not been brought into the religious, political and social reformation. 
Thus, religion paves the way for understanding the life with the religious identity. Otherwise, in terms of rest of the human life no difference is found between Hindu and Christian whichever the religion is belong does not matter because their livelihood depend on labour power.

Table -3

Community Wise Classification of the Respondents

\begin{tabular}{|r|l|l|l|}
\hline S. No & Caste & No. of Respondent & Percentage \\
\hline 1. & B.C & 24 & 63.15 \\
\hline 2. & S.C & 14 & 36.84 \\
\hline \multicolumn{2}{|r|}{ Total } & 38 & 100 \\
\hline
\end{tabular}

Sources: Primary data

This table - 3 reveals that more than $63 \%$ of the respondents are belonging to backward community and $36.84 \%$ of the respondents are belonging to scheduled cast. The community wise classification of the respondent's even though comes under two sections but in reality it is only a government based classification because all of them are related both in terms of blood and in terms of marriage. The converted Christians are considered as $\mathrm{BC}$. That is the only difference. There is no difference in terms children's education, employment, marriage etc. They still remain to be agriculture labour. No agricultural labourerturn to be landlord or industrialist " or politician or government servant.

Table - 4

\section{Details of Respondents' Education}

\begin{tabular}{|l|l|l|l|}
\hline $\begin{array}{l}\text { S. } \\
\text { No }\end{array}$ & Education & $\begin{array}{l}\text { No. of } \\
\text { Respondent }\end{array}$ & Percentage \\
\hline 1. & $\begin{array}{l}\text { Non formal } \\
\text { Education }\end{array}$ & 6 & 15.78 \\
\hline 2. & Primary School & 2 & 5.26 \\
\hline 3. & Middle School & 12 & 31.57 \\
\hline 4. & High School & 16 & 42.10 \\
\hline 5. & $\begin{array}{l}\text { Higher } \\
\text { Secondary }\end{array}$ & 2 & 5.26 \\
\hline \multicolumn{2}{|l|}{ Total } & 38 & 100 \\
\hline
\end{tabular}

Sources: Primary data

This table shows that $15.75 \%$ of the respondents are illiterates, $5.26 \%$ of the respondents attained primary school education. $31.57 \%$ of the respondents have completed middle school education. $42.10 \%$ of the respondents have completed high school education and $5.26 \%$ of the respondents have completed higher secondary school (HSS) education.Thus, majority of the respondents have completed school education and could not go for higher education due to financial scarcity. They don't have the regular income and they have to take care of others. That is why they are not able to reach the higher education. Poverty leads to illiteracy and ignorance.

The analysis of educational background of women agricultural labourer brought out social fact that women are not allowed to study beyond high school education. Instead their physical power is used to get employment daily and offer income for their family expenses, dress materials and savings for marriage expenditure. Thus on the one hand education is considered to be obstacles and on the other it requires extra income for the parents. Thus the net effect- is women from agricultural labourer households still continue to less educated, less knowledgeable and offer fiscal labour to this country.

\section{Table - 5}

\section{Respondents' Family Size}

\begin{tabular}{|r|l|l|l|}
\hline $\begin{array}{l}\text { S. } \\
\text { No }\end{array}$ & Type of Family & $\begin{array}{l}\text { No. of } \\
\text { Respondent }\end{array}$ & Percentage \\
\hline $56=6$. & $\begin{array}{l}\text { Nuclear family } \\
(1-4)\end{array}$ & 31 & 81.57 \\
\hline $\begin{array}{r}2 . \\
\text { Joint family } \\
(4-7)\end{array}$ & 7 & 18.42 \\
\hline \multicolumn{2}{|c|}{ Total } & 38 & 100 \\
\hline
\end{tabular}

Sources: Primary data

This table - 5 shows that more than $80 \%$ of the respondents belong to nuclear family and remaining are Joint family. The reason for many of them remind in nuclear family is presented by respondents that the income is not is sufficient for joint family. It is not even fulfilling the requirements of nuclear family. Hence they feel it is difficult to living joint family.

Moreover joint family is a prerequisite for landed property. Then the property is larger it lands to fragmentation of the land which is not accepted by the members of the joint family. Whereas in the case of the land less labours, they have nothing to lose and nothing to gain to follow a particular family system. Thus it is meaningless to address the system of family 
International Journal of Trend in Scientific Research and Development (IJTSRD) ISSN: 2456-6470

for the agricultural labourers. The only issue is how income which reminds to be questions for ever. do the support the elderly people in the absence of the

Table - 6: Family Income

\begin{tabular}{|c|c|c|c|}
\hline$\overline{\text { S. No }}$ & $\begin{array}{l}\text { Family Income } \\
\text { (Per Annum) }\end{array}$ & No. of Respondent & Percentage \\
\hline 1. & $25,000-50,000$ & 22 & 57.89 \\
\hline 2. & $50,000-75,000$ & 16 & 45.10 \\
\hline & Total & 38 & 100 \\
\hline
\end{tabular}

Sources: Primary data

This table shows that Annual income of the family, they are getting employment for few days only and maximum numbers of respondents are getting 25,000- rest of the days they are unemployed.

50,000 income per year.

Table - 7: Acres of Land

\begin{tabular}{|c|l|l|l|}
\hline \multicolumn{1}{l|}{$\begin{array}{l}\text { S. } \\
\text { No }\end{array}$} & $\begin{array}{l}\text { Acres of } \\
\text { land }\end{array}$ & $\begin{array}{l}\text { No. of } \\
\text { Respondent }\end{array}$ & Percentage \\
\hline 1. & No land & 24 & 63.16 \\
\hline 2. & 1 Acre & 8 & 21.05 \\
\hline 3. & 2 Acre & 6 & 15.79 \\
\hline \multicolumn{2}{|l|}{ Total } & 38 & 100 \\
\hline
\end{tabular}

Sources: Primary data

This shows that $65.78 \%$ of the respondents have no lands. So they are labours. $18.42 \%$ of the respondents are having one acre of the land and $15.78 \%$ of the respondents have two acre of the land. In their small size of land the cultivate sesame $\&$ cotton

Table - 8: Type of land

\begin{tabular}{|l|l|l|l|}
\hline $\begin{array}{l}\text { S. } \\
\text { No }\end{array}$ & Type of land & $\begin{array}{l}\text { No. } \\
\text { Respondent }\end{array}$ & Percentage \\
\hline 1. & Wet Land & 7 & 18.42 \\
\hline 2. & Dry Land & 6 & 15.78 \\
\hline 3. & No Land & 25 & 65.78 \\
\hline \multicolumn{2}{|l|}{ Total } & 38 & 100 \\
\hline
\end{tabular}

Sources: Primary data

This table reveals that $21.05 \%$ of the respondents have wet land, $15.78 \%$ of the respondents have dry land and more than $63.16 \%$ of the respondents have no land. Thus, few respondents are cultivating at any time because they are not depending on monsoon and they have kept bore well and some irrigation facility. So majority of the respondents are wage labourers and

\section{Table - 9: Details of Respondents' work Experience}

\begin{tabular}{|r|l|l|l|}
\hline \multicolumn{1}{|l|}{$\begin{array}{l}\text { No } \\
\text { No }\end{array}$} & Year & $\begin{array}{l}\text { No. } \\
\text { Respondent }\end{array}$ & of \\
\hline 1. & $1-5$ Year & 2 & 5.26 \\
\hline 2. & $6-10$ Year & 4 & 10.52 \\
\hline 3. & $11-15$ Year & 6 & 15.78 \\
\hline 4. & $\begin{array}{l}\text { Above16 } \\
\text { Years }\end{array}$ & 26 & 68.42 \\
\hline Total & 38 & 100 \\
\hline
\end{tabular}

Sources: Primary data

This table indicates that $5.26 \%$ of the respondents are working as agricultural labourers from 1- 5 years. $10.52 \%$ are becoming the agricultural labourers from 6-10 years. $15.78 \%$ are agricultural labourers for 11 15 years and majority of the $(68.42 \%)$ respondents are agricultural labours for more than 16 years. They have known agricultural work only that is why they are unable to go for urban for doing other works. The first groups are engaged in plantation of crops in the beginning \& weeding the crops during the crops of cultivation. They are not engaged in reaping the grams, reaping the cotton and cutting the bunds at the time of paddy harvest since it requires lot of experiences \& skill based on their experience. The second \& third group are involved in all activities including harvest. Whereas the fourth groups do the co-ordination work of recruiting the agricultural laboures and collection\& distribution the wages for the labours. They also supervise their work to complete their process in time. Thus depending upon their experience the women agricultural labours classified into 4 groups \& accordingly they perform various activities. 
Table - 10: Respondents' involvement in NonAgriculture work

\begin{tabular}{|r|l|l|l|}
\hline $\begin{array}{l}\text { S. } \\
\text { No }\end{array}$ & Work & $\begin{array}{l}\text { No. } \\
\text { Respondent }\end{array}$ & Percentage \\
\hline 1. & Yes & 30 & 78.94 \\
\hline 2. & No & 8 & 21.05 \\
\hline Total & 38 & 100 \\
\hline
\end{tabular}

Sources: Primary data

This table shows that majority $78.94 \%$ of the respondents are involving in non-agricultural work (eg), tailoring, cattle farm, MNRGES etc., and $21.05 \%$ of the respondents are not involving in non agricultural work because they know this work only and they are aged.

Table - 11: Distribution of Respondents by long year of Non- agricultural work

\begin{tabular}{|r|l|l|l|}
\hline \multicolumn{1}{|l|}{$\begin{array}{l}\text { No } \\
\text { No }\end{array}$} & Year & $\begin{array}{l}\text { No. of } \\
\text { Respondent }\end{array}$ & Percentage \\
\hline 1. & $1-5$ Year & 3 & 7.89 \\
\hline 2. & $\begin{array}{l}6-10 \\
\text { Year }\end{array}$ & 24 & 63.15 \\
\hline 3. & $\begin{array}{l}11-15 \\
\text { Year }\end{array}$ & 11 & 28.94 \\
\hline Total Trend & 38 & 100 \\
\hline
\end{tabular}

Sources: Primary data

This table shows that $7.89 \%$ of the respondents are involving in Non- agricultural work from tailoring (15 years,). Majority (63.15\%) of the respondents are doing this work MNRGES in 6-10 years and $28.94 \%$ of the respondents are involving in Nonagricultural work in cattle farm (11-15 years). Thus, majority of the workers are becoming agricultural workers (6- 10 years). They have known only this work and they do not know other works like urban people. They are engaged in cattle breeding, selling
Vegetables \& fruits, Tailoring and other such activities.

\section{Table - 12: Distribution of Respondents by social problems}

\begin{tabular}{|r|l|l|l|}
\hline S. No & Problems & $\begin{array}{l}\text { No. of } \\
\text { Respondent }\end{array}$ & Percentage \\
\hline 1. & Disease & 3 & 7.89 \\
\hline 2. & Poverty & 10 & 26.31 \\
\hline 3. & $\begin{array}{l}\text { Un } \\
\text { Employment }\end{array}$ & $\begin{array}{l}\text { No Pucca } \\
\text { House }\end{array}$ & 55.26 \\
\hline Total & D & 38 & 10.52 \\
\hline
\end{tabular}

Sources: Primary data

This table shows that $7.89 \%$ of the respondents are having disease like cancer. $6.31 \%$ of them are struggling for daily food. More than $55 \%$ of the respondents are in unemployment work problems, and $10.52 \%$ of the respondents have no Pucca house. Thus, all of the respondents are involving in agricultural work. So they do not able to find other alternative work to solve their problems.

\section{Table - 13: Distribution of Respondents by} discrimination in working place

\begin{tabular}{|c|l|l|l|}
\hline $\begin{array}{c}\text { S. } \\
\text { No }\end{array}$ & Discrimination & $\begin{array}{l}\text { No. of } \\
\text { Respondent }\end{array}$ & Percentage \\
\hline 1. & Having & 9 & 23.68 \\
\hline 2. & Not having & 29 & 76.31 \\
\hline \multicolumn{2}{|c|}{ Total } & 38 & 100 \\
\hline
\end{tabular}

Sources: Primary data

This table shows that $23.68 \%$ of the respondents are facing discrimination in caste and religion and rest of them do not have any discrimination andmajority of the $76.31 \%$ agricultural labours no discrimination. 
International Journal of Trend in Scientific Research and Development (IJTSRD) ISSN: 2456-6470

Table - 14: Respondents' Expectation from Government and non-Government

\begin{tabular}{|c|l|l|l|}
\hline S. No & Expectation & No. of Respondent & Percentage \\
\hline 1. & Lone With Subsidy & 1 & 2.63 \\
\hline 2. & Micro Credit & 5 & 13.15 \\
\hline 3. & Training With Salary & 2 & 5.26 \\
\hline 4. & Lone In Low Interest for & 6 & 63.15 \\
\hline 5. & $\begin{array}{l}\text { Modern Technology Purpose } \\
\text { Agricultural fil }\end{array}$ & 38 & 15.78 \\
\hline Total & & 100 \\
\hline
\end{tabular}

Sources: Primary data

This table reveals that $2.63 \%$ of the respondents are expecting loan with subsidy from Govt. $13.15 \%$ of the respondent are excepting microcredit from $\mathrm{NGO}$ and Govt. $5.26 \%$ of the respondents are excepting vocational training with salary from NGO and Govt. $63.15 \%$ of the respondent want to improve in their life economically. So they are expecting loan in low interest. $15.78 \%$ of the respondents are excepting modern technology for agricultural work. Thus, the Government and NGO should motivate the agricultural workers. They should be provided proper training on the rural fulfillment.

\section{Conclusion}

More than two-thirds of the population of India is dependent on agriculture. Though Green Revolution technologies enhanced agricultural productivity, they also widened economic disparities and deepened gender discrimination in community life. The introduction of capital intensive technologies in the agricultural sector has had differential impact on men and women and women have been adversely affected due to lack of access to technology. Agriculture is the back bone of many developing countries. Women account for more than half of the work force by participating in different activities, either directly or indirectly. The gender division of labor varies from one society and culture to another, and within each culture external circumstances influence the level of activity.

However, except in few most developed countries, women's efforts are not yet realized by society. In order to guarantee sustainable agricultural development in the new millennium, rural workers and their families should have access to adequate working and living conditions, health and welfare. An adequate balance between agricultural growth and the protection of the environment is also crucial for the future of the world's food production and for its sustainability. Occupational health in agriculture must be integrated into a rural development policy with a well-defined strategy. It should place an emphasis on prevention and environmental protection to be consistent with current trends and should be addressed both at national and international levels.

\section{Socio economic condition:}

Age wise 5 sections women agricultural labours are classified. Among them only the middle age agricultural labours get offer frequently \& preferred by the land lords. Aged women are not preferred for many reasons. All their life is exhausted during their middle age. However their contribution to the society is very critical as found in the study. They face problems in the family, in the working place $\&$ in the end they found nobody to help them. They get in to indebtedness trap and could not come out of it.

Hence the society needs defense mechanism to enhance the women particularly agricultural labourers. All the respondents be longs to two religion rarely Hindu \& Christianity. But the analysis shouts this religions difference does not have any impact upon their education, standard of living, awareness, and empowerment the community wise clarification has two sections even though there is no difference in their education, employment, marriage etc. They remind to be agricultural labourers for many generations.

Education wise none of them went for higher education. most of them are at high school level. Their physical labourer is used the rural society. The development through education was not received by them where as education to be is considered an 
obstacles by the parents. The net effect is women agricultural labourers are less educated in the post, \& present the future is the hands of the decision makers the study is dominated by nuclear family \& joint family is disintegrating some of them have small amount of land in which cultivate sesame, cotton \& grams they have reported lot of problems of health, indebtedness, standard of living taking care of the aged people etc.

The study recommends for living loan to start small enterprises to depend upon their own efforts. It recommends international training like tailoring, embroidering, mobile repairing, baric computer training, TV repairing, electrical and electronics, laptop service. Thus the isolated social problem of women agricultural labourer is presented by the study by which government \& non- government organization must explore the possibilities of development in their life.

\section{REFERENCE}

1. Agarwal, Bina (1994) “A Field of One's Own: Gender and Land Rights in South Asia. New York", Cambridge University Press.

2. Cloud K, In: Gender roles in development projects: a case book, edited by Catherine Overholt, Mary B. Anderson, Kathleen Cloud and James E. Austin. West Hartford, Connecticut, Kumarian Press, 1985. 17-56.

3. Eapen, Mridul. "Rural Non-Agricultural Employment in Kerala: Some Emerging Tendencies", Economic and Political Weekly, 24 (21). 1994.

4. K. Devaki, Senthilkumar andSubramania(2015), International Journal of Science, Environment and Technology, Vol. 4, 5, pp. 1322 - 1329.

5. Kaleeswaran and C.Rajalakshmi (2015) Contribution of Female Labour in Agriculture: A Case Study of Erode District of Tamil Nadu International Journal of Scientific and Research Publications Volume 5, (8).

6. MakbulHussain Khan Balikuri, Barpeta (2013), "Women in Agriculture women are almost help of the adult population", The International Journal of Engineering and Science, Vol. 2, No. 3,pp. 1921.
7. RajulaShanthy (2009) Efficiency of Women Agricultural Labourers in Rice Farming Systems of Kerala and Tamil Nadu Indian Res. J Ext. Edu. 9 (2) Senior Scientist (Agril. Extension), Sugarcane Breeding Institute.

8. Rachel Ann Rosenfeld (1985) Farm Women: Work, Farm, and Family in the United StatesOxford University PressVol. 66, (1) pp. 283-285.

9. RajulaShanthy (2009) Efficiency of Women Agricultural Labourers in RiceFarming Systems of Kerala and Tamil Nadu.Indian Res. J Ext. Edu. 9 (2).

10. RoshanLal and Ashok Khorana (2011) gender issues: the role of women in agriculture sector International Journal of Business Economics \& Management Research Vol.1 http://zenithresearch.org.in/ www.zenithresearch.org.in.

11. Subadevy (2015) Socio economic conditions of landless agricultural female labours in Thanjavur EPRA international journal economic and business Review vol - 3 (12). 